\title{
Espectro funcional de bem e bom no português falado: instâncias de gramaticalização
}

\author{
Edair Maria GÖRSKI (D) \\ Universidade Federal de Santa Catarina (UFSC)
}

\section{ఠ}

OPEN ACCESS

\section{EDITADO POR \\ - André Vinicius Lopes Coneglian (UFMG) \\ - Maria Helena de Moura Neves (UNESP) \\ - Lachlan Mackenzie (VUA)}

AVALIADO POR

- Gaston Hilgert (MACKENZIE)

- Marcelo Modolo (USP)

DATAS

- Recebido: 11/10/2020

- Aceito: 18/11/2020

- Publicado: 17/12/2020

\section{COMO CITAR}

Görski, E. M. (2020). Espectro funcional de beme bom no português falado: instâncias de gramaticalização. Revista da Abralin, v. 19, n. 3, p. 131-158, 2020.

\section{RESUMO}

Numa abordagem funcionalista de gramática (cf. GIVÓN, 2001; 2018), o trabalho objetiva (i) apresentar uma descrição qualitativa e quantitativa do leque de funções desempenhadas por bem e bom, considerando tanto o estatuto gramatical prototípico de advérbio e adjetivo, respectivamente, quanto os usos discursivos como marcadores e outros possíveis usos, a partir do exame de situações dialógicas em 72 entrevistas sociolinguísticas (Projeto VARSUL); (ii) tratar comparativamente os usos discursivos, buscando padrões contextuais de comportamento; e (iii) analisar as mudanças envolvidas como instâncias de gramaticalização (cf. HIMMELMANN, 2004; TRAUGOTT, 2010a; DIEWALD (2011b). Entre os resultados destacam-se: (i) em termos frequenciais, o uso de bem adverbial é significativamente maior que o uso de bom adjetival; como marcador discursivo, bom é largamente mais usado que bem; e em outros usos, bem supera bom, apresentando um comportamento mais polissêmico; (ii) como marcadores discursivos, os itens compartilham uma propriedade geral textual/interpessoal e sinalizam um duplo movimento (de estruturação discursiva e de negociação), com presença significativa encabeçando respostas imediatas, mas apresentam especificidades contextuais de uso: enquanto bom predomina em abertura de turno, particularmente introduzindo preâmbulo, bem prevalece em posições intraturno, em contextos de organização tópica, especialmente de sequenciação e retomada do fluxo discursivo, incidindo sobre a fala do próprio informante; (iii) os marcadores apresentam padrões contextuais distintos na fala do informante e na fala do entrevistador. Conclui-se que o funcionamento dos itens é dependente do tipo de situação 


\section{REVISTA DA ABRALIN}

comunicativa e aponta-se a necessidade de as análises considerarem os gêneros textuais/ discursivos e suas particularidades, especialmente em estudos comparativos.

\section{ABSTRACT}

In a functionalist approach to grammar (cf. GIVÓN, 2001; 2018), the work aims (i) to present a qualitative and quantitative description of the range of functions performed by bem (well) and bom (good), considering both the prototypical grammatical status of adverb and adjective, respectively, as for the discursive uses as markers and other possible uses, from the examination of dialogical contexts in 72 sociolinguistic interviews (VARSUL Project); (ii) to treat comparatively the discursive uses, seeking contextual patterns of behavior; and (iii) to analyze the changes involved such as instances of grammaticalization (cf. HIMMELMANN, 2004; TRAUGOTT, 2010a; DIEWALD (2011b). Among the results we highlight: (i) in terms of frequency, the adverbial use of bem is greater than the adjetival use of bom; as a discourse marker, bom is more widely used than bem; and in other uses, bem presents a more polysemic behavior than bom; (ii) as discourse markers, the items share a general textual / interpersonal property and they signal a double movement (of discursive structuring and negotiation), with significant occurrence introducing immediate responses, but they present contextual specificities of use: while bom predominates in opening shifts, introducing particularly preamble, bem prevails in intraturn positions, in contexts of topical organization, especially of sequencing and resuming the discursive flow, focusing on the informant's own speech; (iii) the markers present different contextual patterns in the informant's speech and in the interviewer's speech. It is concluded that the functioning of the items is dependent on the type of communicative situation and the need for the analysis to consider textual / discursive genres and their particularities is pointed out, especially in comparative studies.

\section{PALAVRAS-CHAVE}

VARSUL. Contextos dialógicos. Multifuncionalidade. Bem e bom. Gramaticalização.

\section{KEYWORDS}

VARSUL. Dialogical contexts. Multifunctionality. Bem (well) and bom (good). Grammaticalization. 


\section{REVISTA DA ABRALIN}

\section{Introdução}

Os itens bem e bom, categorizados em sua origem como advérbio (do latim bene) e adjetivo (do latim bonus, a,um), respectivamente, apresentam em português, ao lado de seu uso categorial prototípico, também a função de marcadores discursivos (MDs), além de alguns outros usos. Sob perspectivas teóricas distintas, inúmeros trabalhos descrevem o funcionamento dessas partículas e seus correlatos em diferentes línguas, dentre os quais mencionam-se os seguintes: Risso (1999; 2006) e Martins (2003) analisam bem e bom em amostras do português falado contemporâneo; Travis (1998) e Serrano (1999) analisam bueno no espanhol falado; De Fina (1997) investiga o uso de bien no espanhol falado; Waltereit e Detges (2007), além de abordarem sincronicamente o uso de bien e bueno no espanhol, descrevem diacronicamente o uso de bien no espanhol e no francês; Defour (2007) faz um estudo diacrônico de well no inglês; Sakita (2013) e Heritage (2015) analisam o uso de well em dados sincrônicos de interação conversacional natural no inglês. Tais autores focalizam especificamente o funcionamento de bem e/ou bom (e correlatos em outras línguas) como partículas discursivas, pragmáticas ou MDs.

A proposta deste estudo é de apresentar um panorama do funcionamento dos itens bem e bom no português falado, com base no exame de dados gerados a partir de entrevistas sociolinguísticas do Projeto VARSUL ${ }^{1}$. São considerados tanto as categorias gramaticais de advérbio e adjetivo, respectivamente, quanto os usos discursivos como marcadores e outros possíveis usos, buscando depreender padrões de comportamento. As mudanças envolvidas são interpretadas como instâncias de gramaticalização.

Cabe registrar que este trabalho reexamina parte do corpus analisado por Martins (2003), constituindo uma nova amostra a partir da qual são categorizadas todas as ocorrências desses itens (não só como marcadores) e reanalisados os contextos de atuação dos MDs sob outros critérios, de modo a captar o espectro da multifuncionalidade dos itens e instâncias de gramaticalização.

O artigo se desenvolve com as seguintes seções: uma que apresenta a concepção de língua, gramática e gramaticalização assumida; outra que expõe alguns trabalhos sobre o funcionamento discursivo de bem e de bom (e correlatos em outras línguas); uma terceira que descreve o encaminhamento metodológico; e, por fim, uma seção que apresenta a análise da multifuncionalidade desses itens no português falado, seguida de considerações finais.

\section{Abordagem teórico-conceitual}

\footnotetext{
${ }^{1}$ Informações disponíveis em: < $\underline{\text { http: //www.varsul.org.br }>}$
} 


\section{REVISTA DA ABRALIN}

Ao se tratar de fenômenos linguísticos em mudança, é necessário inicialmente explicitar, no âmbito geral de uma abordagem funcional, qual é a concepção de língua, de gramática e de gramaticalização adotada, bem como definir MDs, no caso específico deste artigo. Assume-se a concepção funcionalista de língua e de gramática de Givón (2001; 2018): (i) a língua desempenha duas funções principais: de representação mental e de comunicação do conhecimento/experiência; (ii) o sistema de representação mental recobre o léxico conceptual, a semântica proposicional e o discurso multiproposicional (ou a pragmática discursiva), que correspondem a três "megadomínios" funcionais da linguagem - palavras, proposições e discurso; e (iii) a gramática codifica, articuladamente, os níveis da semântica proposicional e da pragmática discursiva, e seu escopo recai "predominantemente sobre as relações de coerência entre a proposição (oração) e o contexto comunicativo mais amplo, seja o texto corrente, seja a situação de fala face a face e, nesta última, a interação falante-ouvinte"² (GIVÓN, 2018, p. 35). Nessa visão alargada, portanto, a gramática envolve além do nível estritamente estrutural também o nível semântico-pragmático.

Nessa mesma linha, Degand e Evers-Vermeul (2015) - fazendo eco a Traugott (1995; 2003), Brinton e Traugott (2005), entre outros - consideram que a pragmática não deve ser excluída da gramática, uma vez que categorias tidas como estritamente gramaticais (como tempo, aspecto e modo) desempenham funções pragmáticas, assim como categorias discursivas (como tópico e foco) podem exibir uma dimensão gramatical. Nos termos de Traugott (2003, p. 626):

A gramática abrange fonologia, morfossintaxe e semântica funcional da verdade, e é rica o suficiente para licenciar a interação com as habilidades cognitivas gerais, como as que estão envolvidas na negociação falante-ouvinte que dá origem à gramaticalização. Essas incluem processamento de informações, gerenciamento de discurso e outras habilidades centrais à pragmática linguística de focalização, topicalização, dêixis e coerência discursiva. ${ }^{3}$ (TRAUGOTT, 2003, p. 626; grifo acrescido)

Diewald (2011a) acrescenta outro componente na definição de gramática que é pertinente à presente discussão: o significado relacional (além da obrigatoriedade e da integração paradigmática), que diz respeito à indexicalidade inerente de itens gramaticais, que "estabelecem um elo entre dois pontos [...] o ponto de ancoragem da relação é o dêitico origo ou um de seus 'derivados"'4 (DIEWALD, 2011a p. 360). A ideia de dêitico origo refere-se à noção bühleriana de um ponto abstrato tipicamente localizado no falante, mas que pode ser transferido para outros locais, de modo a se estabelecer uma ligação entre um elemento linguístico com outro ou com alguma entidade não linguística relevante. Assim vista, a

\footnotetext{
${ }^{2}$ No original: "[...] predominantly about the coherence relations between the proposition (clause) and the wider communicative context, be it the current text, the face-to-face speech situation and, within the latter, the speaker-hearer interaction."

${ }^{3}$ No original: "Grammar encompasses phonology, morphosyntax, and truth-functional semantics, and is rich enough to license interaction with the general cognitive abilities such as are involved in the speaker-addressee negotiation that gives rise to grammaticalization. These include information processing, discourse management, and other abilities central to the linguistic pragmatics of focusing, topicalization, deixis, and discourse coherence."

${ }^{4}$ No original: "[...] a relational structure which establishes a link between two points [...] the anchoring point of the relation is the deictic origo or one of its 'derivatives'."
} 


\section{REVISTA DA ABRALIN}

conectividade não se limita ao nível sintático/textual, mas pode ser estabelecida com elementos do contexto comunicativo. A autora defende que a gramática é fundamentalmente enraizada na pragmática, como já postulava Givón (1979), em obra seminal que teve edição revisada (2018).

O segundo conceito que requer explicitação é o de gramaticalização. Parte-se da seguinte definição: "mudança pela qual itens e construções passam, em certos contextos linguísticos, a desempenhar funções gramaticais, e uma vez gramaticalizados, continuam a desenvolver novas funções gramaticais"5 (HOPPER; TRAUGOTT, 2003, p. xv; grifos acrescidos). Note-se que tal definição se distancia da noção clássica que contempla a trajetória léxico > elemento gramatical > elemento mais gramatical (voltada para perda e redução de elementos semânticos, morfológicos e fonéticos) ${ }^{6}$, colocando relevo na ideia de "novas funções gramaticais" em vez de "funções mais gramaticais", e no papel do contexto, uma vez que a mudança não atinge um item isoladamente e nem um item em todos os seus usos de uma vez.

Dada a natureza dos MDs, o tipo de abordagem de gramaticalização mais adequado para esse fenômeno é aquele identificado como expansão (cf. HIMMELMANN, 2004; BRINTON; TRAUGOTT, 2005; TRAUGOTT, 2010a; entre outros), em que ganham destaque: a participação ativa dos interlocutores como criadores de novos usos, com expansão contextual e fortalecimento pragmático mediante reinterpretação induzida pelo contexto, podendo envolver instâncias de (inter)subjetivização (cf. TRAUGOTT, 1995, 2002, 2008; 2010b; TRAUGOTT; DASHER, 2002; HOPPER; TRAUGOTT, 2003); bem como o papel da frequência na rotinização e convencionalização de novos usos (cf. BYBEE, 2003); entre outros aspectos. Movimentos de (inter)subjetivização são relacionados ao direcional proposicional > textual > interpessoal (cf. HALLIDAY, 1994), sendo esta última função - considerada por Traugott como expressiva - desdobrada nos componentes subjetivo > intersubjetivo (TRAUGOTT; DASHER, 2002).

É na perspectiva da gramaticalização como expansão que Himmelmann (2004), focando nos ganhos, propõe que as mudanças se acomodam, em alguma medida, aos seguintes critérios: (i) expansão de classe hospedeira - aumento na coocorrência com diferentes tipos de constituintes (incluindo entidades discursivas); (ii) expansão sintática - ampliação do escopo estrutural, por exemplo, em relação à posição; e (iii) expansão semântico-pragmática - multifuncionalidade (principal traço definidor da gramaticalização, segundo o autor).

Tanto a concepção de gramática como a de gramaticalização apresentadas colocam em cena a pragmática. Tem havido um amplo debate na literatura contemporânea acerca do processo envolvido no desenvolvimento de MDs: gramaticalização ou pragmaticalização, ou nenhum deles (cf. DIEWALD, 2011b; HEINE, 2013; DEGAND; EVERS-VERMEUL, 2015; entre outros). Diewald (2011b), por exemplo, sugere tratar a gramaticalização como um processo superordenado que envolve

\footnotetext{
${ }^{5}$ A palavra construção é usada nessa definição e neste artigo em seu sentido pré-teórico, designando um constituinte.

${ }^{6}$ Cf., por exemplo, a definição de Kurylowicz (1965, p. 69): "gramaticalização consiste no aumento do alcance de um morfema, passando de um status lexical para um gramatical ou de um status menos gramatical para um mais gramatical". No original: "grammaticalization consists in the increase of the range of a morpheme advancing from a lexical to a grammatical or from a less grammatical to a more grammatical status."
} 


\section{REVISTA DA ABRALIN}

subjetivização e pragmaticalização, posição também assumida neste trabalho, admitindo-se que o primeiro é mais abrangente e abriga o segundo: "pragmaticalização é um tipo específico de gramaticalização" (DIEWALD, 2011b, p. 384). Considera-se, pois, que os MDs fazem parte da gramática, uma vez que desempenham funções gramaticais ao "relacionar um enunciado à situação do discurso, mais especificamente à interação falante-ouvinte, às atitudes do falante e/ou à organização de textos"7 (HEINE, 2013, p. 1211). Como este trabalho é de natureza sincrônica, busca-se identificar instâncias de gramaticalização em usos emergentes e em padrões recorrentes em contextos discursivos pragmaticamente motivados (TRAUGOTT; HEINE, 1991), notadamente em situações dialógicas ${ }^{8}$ (TRAUGOTT, 2010c).

Acredita-se - como Defour (2007), em seu estudo sobre a multifuncionalidade de well no inglês - que a gramaticalização pode explicar tanto a coexistência sincrônica de uma forma com diferentes significados proposicionais e pragmáticos, como o desenvolvimento e diversificação funcional de múltiplos significados a partir de um dado elemento proposicional, especialmente movimentos que, em situações dialógicas, envolvem aumento de subjetivização (base para consideração ativa do turno precedente e desenvolvimento de uma posição pessoal) e de intersubjetivização (atenção à face do interlocutor e criação de uma base comum de compreensão).

Outro aspecto relacionado à gramaticalização que é relevante a este artigo diz respeito aos princípios postulados por Hopper (1991), especialmente: estratificação - camadas/formas novas e antigas podem coexistir dentro de um mesmo domínio funcional; divergência - formas lexicais originais podem permanecer em uso ao lado de formas inovadoras; persistência - traços de significado lexical original tendem a aderir à forma em gramaticalização; especialização - num amplo domínio funcional, uma dentre as formas disponíveis em dado estágio assume significados gramaticais mais gerais (generalização); ou ainda, as formas podem coexistir dividindo funções (especialização) (TAVARES, 1999).

\section{Sobre o funcionamento de bem e bom como MDs: alguns estudos prévios}

Alguns estudos voltados ao uso discursivo de bem e bom, e correlatos bien, bueno e well em outras línguas, são brevemente apresentados a seguir como subsídios à análise na seção seguinte.

\footnotetext{
${ }^{7}$ No original: "The main function of DMs is to relate an utterance to the situation of discourse, more specifically to speaker-hearer interaction, speaker attitudes, and/or the organization of texts."

${ }^{8}$ O termo dialógico(a) é usado neste trabalho em referência à situação de interlocução que envolve não só a troca de turnos (com a estratégia dialogal de pergunta-resposta), mas também a expressão/invocação de pontos de vista (contestação, construção de um argumento etc.).
} 


\section{REVISTA DA ABRALIN}

Waltereit e Detges (2007) abordam o uso dos marcadores bien ('bem') e bueno ('bom') no espanhol, afirmando que ambos costumam ser tratados em conjunto como mecanismos de negociação da coerência discursiva em situações em que a coerência se mostre em risco: em fechamento de tópico em curso na fala do interlocutor e começo de um novo tópico pelo falante; quando o falante discorda da argumentação do interlocutor; em abertura de turno, em respostas que não convergem diretamente com as expectativas contidas na pergunta. No caso de pergunta-resposta, ambos os marcadores são usados para sinalizar a existência de algum tipo de incompatibilidade entre o conteúdo da pergunta e o teor da resposta - o falante sinaliza que vai modificar, em alguma medida, o rumo da conversa -, mas com uma diferença: bueno pode ser usado para reparar qualquer tipo de incompatibilidade entre o que é projetado na pergunta e a resposta a ser dada (o falante aceita parcialmente e ratifica), ao passo que bien parece ser especializado em contextos em que a resposta exige mais esforço de elaboração e maior complexidade do que a pergunta sugere. Os autores mencionam ainda a possibilidade de os itens serem usados para introduzir uma resposta direta em consonância com o que a pergunta pressupõe.

Num olhar diacrônico, Waltereit e Detges verificam que bien como MD é encontrado no espanhol entre os séculos XVIII e XIX. Em seu desenvolvimento, a partir do traço de avaliação positiva contido no significado de origem do item, ainda como advérbio passa a indicar, por transferência metonímica baseada em inferência, (i) que o falante concorda com o que foi dito antes; (ii) que o falante primeiro admite a validade do argumento, mas depois apresenta um contra-argumento mais forte [valor concessivo: bien... pero (bem... mas)] Esse tipo de contexto específico poderia explicar o surgimento de bien como conector concessivo [si bien que (se bem que)]. Os autores interpretam as mudanças envolvidas como casos de subjetivização (cf. TRAUGOTT; DASHER, 2002).

Analisando bueno numa perspectiva da metalinguagem semântica natural (cf. WIERZBICKA, 1996), Travis (1998) identifica quatro funções para seu uso como MD em gravações de conversa do espanhol colombiano: de aceitação, de aceitação parcial, de reorientação de tópico e de correção. Dado o fato de que as três últimas são inter-relacionadas e apresentam traços de sobreposição, acaba propondo duas funções: uma de aceitação plena e outra de resposta parcial, que agrega também reorientação e correção (o falante aceita, mas acrescenta algo mais).

Serrano (1999), por sua vez, num estudo sociolinguístico examina o funcionamento discursivo de bueno em amostra de entrevistas realizadas na cidade espanhola Santa Cruz de Tenerife, com informantes estratificados por sexo/gênero, faixa etária e nível sociocultural. A autora classifica os usos de bueno em dois tipos de acordo com suas funções discursivas e pragmáticas: marcador de início de turno na conversação e marcador de contraposição. No primeiro caso, bueno serve para manter e orientar a interação comunicativa e tem seu uso associado ao valor positivo original, podendo ser parafraseado por algo como "está bom", "certo, agora eu vou falar". No segundo caso, bueno sinaliza que o falante vai expressar um conteúdo que não está exatamente em conformidade com a posição anterior, discordando de algo que o interlocutor enunciou e introduzindo sua própria ideia sobre o assunto. Como marcador de contraposição, bueno desenvolve um valor oposto ao do seu significado básico, em decorrência de uma "negociação", podendo ser parafraseado por algo 


\section{REVISTA DA ABRALIN}

como "não estou de acordo e vou dizer algo contrário". Os resultados do estudo indicam que esses dois tipos se distribuem de forma relativamente equilibrada entre os informantes.

De Fina (1997) investiga o uso de bien em eventos comunicativos específicos: interações gravadas em aulas de espanhol como língua estrangeira em uma universidade americana, ministradas por professores falantes nativos de espanhol. A autora mostra que bien desempenha duas funções no jogo interativo em sala de aula: uma função transicional, sinalizando movimento de uma situação ou atividade a outra (uma espécie de marcador de continuidade), e outra avaliativa, sinalizando uma resposta positiva do professor no movimento de feedback de um ciclo pergunta-resposta-feedback (uma espécie de marcador de concordância). De Fina (1997) alerta que os marcadores assumem funções especializadas em certos tipos de discurso, que podem ser diferentes daquelas já descritas para os mesmos itens em outros contextos conversacionais, sendo necessário conhecer a natureza do evento comunicativo em questão. No caso de sua amostra, trata-se de uma situação típica em que há nítido controle da interação por parte de um dos participantes.

No inglês, Defour (2007) realiza uma análise diacrônica a partir de diferentes gêneros discursivos e interpreta a multifuncionalidade de well no escopo de estratégias retóricas, atentando para a influência das relações entre os interlocutores. Na linha da distinção entre significados ideacional, textual e interpessoal (cf. HALLIDAY, 1994), Defour correlaciona o significado semântico dos marcadores ao nível proposicional (uso adverbial de well) e o significado pragmático aos níveis textual (marcador que atua na estruturação do discurso, delimitando turnos e tópicos) e interpessoal (marcador que sinaliza a expressão de um ponto de vista ou de uma atitude subjetiva do falante direcionada a um destinatário). A autora ancora sua análise na abordagem de gramaticalização.

Sakita (2013) analisa o uso de well em dados de interação conversacional natural no inglês à luz da noção de relações sociocognitivas de intersubjetividade construídas pelo engajamento dos coparticipantes num quadro dialógico (cf. DU BOIS, 2007), considerando o item como um "operador de metapostura"9 (p. 82), recurso que gerencia o modo como os falantes se posicionam em relação ao conteúdo proposicional, avaliam, negociam e compartilham posturas, buscam um alinhamento de suas próprias posturas e com as posturas dos interlocutores. O autor encontra a maior parte das ocorrências de well em dois tipos de contexto: sinalizando que a resposta a seguir é inconsistente com o discurso precedente (postura de não conformidade ou divergência com a postura de outros ou com a própria postura precedente - nível interpessoal); e sinalizando mudança ou encerramento de tópico (nível textual). Sakita propõe que a função de operador de metapostura abriga as várias funções já descritas na literatura: marcador de resposta, marcador de insuficiência, prefaciador de uma resposta negativa ou inesperada, sinalizador de mudança de turno ou de tópico, indicador de hesitação diante de uma resposta inconsistente, marcador de atenuação, de polidez etc.

Heritage (2015), numa perspectiva da análise da conversação, investiga o uso de well em aberturas de turnos ('well-prefaced turns'), basicamente em conversas telefônicas gravadas e transcritas, considerando que, nessa posição de abertura, a partícula envolve dois movimentos:

\footnotetext{
${ }^{9}$ No original: "meta-stance operator"
} 


\section{REVISTA DA ABRALIN}

um movimento não marcado, que indica que o próximo turno é congruente com as expectativas estabelecidas no turno precedente; e um movimento marcado, que sinaliza uma espécie de desacordo ou distanciamento em relação a projeções do turno anterior. Seus dados são agrupados em três grandes tipos de contexto: resposta a perguntas polares e $w h-;$ mudança e fechamento de tópico; mudança pessoal de perspectiva, com expressão dos próprios pontos de vista do falante; e 'subcategorias diversas', que reúne os casos que não se encaixam nesses contextos. O autor destaca o papel agentivo do falante e a função de well em início de turno como "um alerta geral de que, no turno subsequente, a perspectiva ou projeto do falante será privilegiada sobre a dos interlocutores"10 (HERITAGE, 2015, p. 101).

No português, Risso (1999; 2006), numa abordagem textual-interativa, examina pares de perguntareposta extraídos de inquéritos do projeto NURC e reúne os itens bom, bem, olha e ah como marcadores discursivos de abertura em estruturas de pares adjacentes, identificando-os como elementos "prefaciadores textual-interativos" (2006, p. 470) com os quais o falante procura ganhar tempo na elaboração de sua resposta ou exposição. Na troca de turnos, funcionam "como sinalizadores de uma sequencialização estrutural dependente do contrato de interlocução firmado no fluxo do diálogo" (RISSO, 2006, p. 471), o que indica seu caráter bidirecional (anafórico e catafórico). Podem atuar também em outros contextos de abertura intratópicos, numa posição intermediária, incidindo sobre aspectos novos de uma informação já em curso: encabeçando "operações de exemplificação, de citações, de reintrodução de uma sequência expositiva temporariamente suspensa, de movimentos argumentativos de ressalvas, concessões, entre outros aspectos" (1999, p. 262). Mesmo em posição intratópica, a autora considera que os itens são usados em processos de abertura e compartilham o papel de prefaciação de algum tipo de operação. No entanto, segundo Risso (2006), enquanto olha e ah apresentam uma natureza predominantemente fática e de automonitoramento, mantendo aberto o canal de interlocução (função mais interpessoal, voltada para a primeira e segunda pessoa), bem e bom são mais direcionados para o caráter argumentativo-referencial da informação (função mais ideacional, voltada para a "não-pessoa") - o que os caracteriza como um fenômeno graduável, com funções não estanques. Os marcadores bem e bom, de acordo com a autora, apresentam por vezes um valor concessivo, na mediação entre concordância e discordância com o ponto de vista do interlocutor, o que lhes confere um caráter polifônico.

Martins (2003), inspirada inicialmente em Risso (1999), caracteriza bem e bom pela propriedade comum de chamada de atenção para a informação numa situação interativa e distribui os dados oriundos de 288 entrevistas sociolinguísticas do Projeto VARSUL em duas macrofunções - articuladora interacional e articuladora textual -, identificando-as em termos de traços contextuais. Com caráter mais interacional, os itens aparecem em contextos de prefaciação, atenuação, questionamento, avaliação e planejamento verbal; com caráter mais textual, os marcadores se manifestam em contextos de sequenciação, finalização, retomada, especificação, enumeração, uso retórico e diretivo. A autora realiza uma análise variacionista ancorada numa perspectiva sociofuncionalista, evidenciando uma

\footnotetext{
${ }^{10}$ No original: "[...] a generalized alert that in the subsequent turn the current speaker's perspective or project will be privileged over that of interlocutors."
} 


\section{REVISTA DA ABRALIN}

frequência bem mais alta de bom em relação a bem e uma tendência de bom se manifestar em contextos com traços mais interacionais e bem em contextos mais textuais.

Observa-se, desse apanhado de trabalhos, que o funcionamento de um dado marcador discursivo varia não só de uma língua a outra como também entre diferentes situações comunicativas dentro de uma mesma língua, uma vez que os itens podem assumir funções especializadas em certos tipos de discurso, que podem estar relacionadas com papéis específicos na interação. Uma entrevista é diferente de uma conversa ordinária, que é diferente de uma sessão terapêutica e de uma interação em sala de aula etc. Daí a importância de se analisar o funcionamento dos itens em diferentes amostras/gêneros, de modo a se ter uma análise geral dos mesmos marcadores, considerando a potencial interferência de variáveis situacionais.

Nota-se também que, embora realizados sob perspectivas teóricas distintas, há uma convergência, explícita ou implícita, entre os estudos quanto ao fato de que (i) a multifuncionalidade dos itens envolve expansões semântico-pragmáticas que permeiam as funções textual e interpessoal, apresentando algum tipo de (inter)subjetivização; (ii) há dois movimentos principais envolvidos: um de organização discursiva, sinalizando abertura/fechamento de turno/tópico (de caráter mais textual); e outro de negociação, sinalizando algum tipo de distanciamento/desacordo/contraposição em relação ao discurso precedente (de caráter mais interpessoal); (iii) o contexto dialógico é o locus privilegiado para a realização dos itens como MDs; (iv) o funcionamento dos itens é dependente do tipo de situação comunicativa. A abordagem de gramaticalização assumida neste trabalho é congruente com essas características gerais.

\section{Encaminhamento metodológico}

Como já antecipado na Introdução, parte do corpus investigado por Martins (2003) foi retomado e nova amostra foi constituída, ampliando-se o escopo de atuação do fenômeno e reanalisando-se parte dos dados. Para este trabalho, foram examinadas 72 entrevistas sociolinguísticas (24 por capital - Florianópolis, Curitiba e Porto Alegre) do banco de dados VARSUL, gravadas na década de 1990. Os informantes são estratificados quanto à idade (de 25 a 49 anos e acima de 50 anos), sexo (masculino e feminino) e escolaridade (primário, secundário e colegial - classificação usada à época). ${ }^{11}$

A configuração de uma entrevista sociolinguística envolve uma relação dialógica entre um entrevistador e o entrevistado, o informante. Em geral, segue um roteiro pré-determinado, embora não rígido, de tópicos a serem abordados com maior ou menor profundidade e extensão a depender da disposição e das características do entrevistado: alguns são mais lacônicos e apenas responsivos, limitando-se a responder as perguntas que lhe são dirigidas; outros são mais expansivos e dialogicamente colaborativos, com uma atitude agentiva por vezes se antecipam às intervenções do

\footnotetext{
${ }^{11}$ Os fatores sociais não são analisados neste artigo.
} 


\section{REVISTA DA ABRALIN}

inquiridor e conduzem o rumo da conversa (cf. VALLE; GÖRSKI, 2014). De qualquer modo, a natureza da entrevista envolve uma situação comunicativa peculiar que requer uma postura colaborativa dos interlocutores e uma predisposição favorável à conversa, especialmente da parte do entrevistado; além disso, trata-se de um evento em que há controle da interação, em maior ou menor grau, por parte de um dos participantes. Esse tipo de situação dialógica relativamente planejada pelo entrevistador deve ter reflexos no funcionamento dos marcadores discursivos.

As entrevistas consideradas são marcadas por sucessivas trocas de turno e, na maior parte das vezes, é o informante que mantém por mais tempo o turno. O entrevistador nem sempre faz perguntas, podendo intervir com comentários; e o entrevistado nem sempre espera o entrevistador concluir sua formulação para tomar o turno. Então, embora se fale em resposta do entrevistado a perguntas do inquiridor, nem sempre a situação dialógica se dá no formato explícito de pergunta-resposta.

Foram levantadas todas as ocorrências de bem e bom na fala dos entrevistados e distribuídas, num primeiro momento, em três grupos para cada item: advérbio/ adjetivo, MD e outros. Além disso, foram também extraídas as ocorrências de bem e bom como MD na fala do entrevistador. Uma vez feita a distribuição categorial geral, passou-se à análise do funcionamento discursivo dos itens, identificando-se os diferentes tipos de contexto em que as partículas atuam tanto na fala do informante como na do entrevistador. Na sequência, foi feito um apanhado de outros usos, de modo a se delinear o espectro de multifuncionalidade dos itens.

\section{Análise e discussão}

Embora o foco principal do trabalho recaia sobre a atuação dos itens como MDs, um panorama geral de todas as ocorrências permite perceber com mais propriedade o funcionamento discursivo dos marcadores. Nesse sentido, esta seção contempla inicialmente um levantamento comparativo dos itens distribuídos em três categorias por capital da Região Sul (cf. Tabela 1). Na sequência, a atenção recai sobre os MDs, tanto na fala dos informantes como na fala dos entrevistadores, e sobre os tipos de contexto encabeçados pelos itens bem e bom (cf. Tabelas 2 e 3). Por fim, são observados outros usos desses itens (cf. Tabelas 4 e 5).

\begin{tabular}{l|c|c|c|c|c|c|c|c}
\hline MDs & \multicolumn{4}{|c|}{ Bem } & \multicolumn{3}{c}{ Bom } \\
\hline Cidade & $\begin{array}{c}\text { Adv } \\
\mathrm{N} / \%\end{array}$ & $\begin{array}{c}\mathrm{MD} \\
\mathrm{N} / \%\end{array}$ & $\begin{array}{c}\text { Outro } \\
\mathrm{N} / \%\end{array}$ & Total & $\begin{array}{c}\text { Adj } \\
\mathrm{N} / \%\end{array}$ & $\begin{array}{c}\mathrm{MD} \\
\mathrm{N} / \%\end{array}$ & $\begin{array}{c}\text { Outro } \\
\mathrm{N} / \%\end{array}$ & Total \\
\hline Fpolis & $424 / 86 \%$ & $11 / 02 \%$ & $58 / 12 \%$ & 493 & $119 / 76 \%$ & $33 / 21 \%$ & $04 / 02 \%$ & 156 \\
\hline Curitiba & $368 / 87 \%$ & $14 / 03 \%$ & $40 / 10 \%$ & 422 & $241 / 63 \%$ & $132 / 35 \%$ & $08 / 02 \%$ & 381 \\
\hline P. Alegre & $337 / 83 \%$ & $04 / 01 \%$ & $66 / 16 \%$ & 407 & $194 / 66 \%$ & $82 / 28 \%$ & $19 / 06 \%$ & 295 \\
\hline Total & $1.129 / 85 \%$ & $29 / 02 \%$ & $164 / 12 \%$ & 1.322 & $554 / 66 \%$ & $247 / 30 \%$ & $31 / 04 \%$ & 832 \\
\hline
\end{tabular}




\section{REVISTA DA ABRALIN}

Observando as cidades, nota-se que cada um dos itens apresenta uma distribuição frequencial equilibrada das três categorias entre as localidades, diferindo apenas em relação ao número total de ocorrências: Florianópolis é a cidade que apresenta a maior polarização no uso dos dois itens e Curitiba é a que apresenta uma distribuição mais aproximada entre eles.

No total de dados, chama a atenção a grande diferença no número de ocorrências de cada item (1.322 dados de bem e 832 dados de bom, o que corresponde a 61\% e 39\% do total de dados, respectivamente), bem como o fato de que o uso prototípico como advérbio (85\%) e adjetivo (66\%) ultrapassa grandemente os demais usos de cada item; além disso, bem adverbial supera em quase $20 \%$ o uso de bom adjetival. Tal comportamento pode ser explicado em termos de escopo e de características morfossintáticas: bem como advérbio prototípico tem escopo sobre um verbo ('canta bem'), um adjetivo ('bem bonito') ou outro advérbio ('muito bem'); bom como adjetivo prototípico tem escopo apenas sobre um substantivo (nome ou pronome), funcionando sintaticamente como adjunto adnominal ('lugar bom') ou como predicativo ('ele é bom'). Além disso, bem é invariável e bom é flexionado em número e gênero (bons, boas) em contextos de concordância nominal, e somente as ocorrências de bom foram consideradas neste trabalho.

Entre os usos adverbiais, encontram-se algumas particularidades: 14 construções em que ao uso proposicional se sobrepõe um uso discursivo (como em "E ele fica calmo, porque, você veja bem, ele fica [..]"12 (CTB Inf. 01); 12 construções em que bem intensifica um nome que funciona como adjetivo (como em "Ela é bem gasolina mesmo" (POA, Inf. 23); e 08 construções de reparo que rumam para a cristalização, com significado de "exatamente" (como em "Era premiação assim, era o mais bonito, não era bem um prêmio [...]" (FLP Inf. 24).

Nas colunas de MD, nota-se que em apenas $2 \%$ das ocorrências do item bem a partícula atua como MD; bom, por sua vez, desempenha essa função discursiva em 30\% dos dados desse item. Já em outros usos, essa distribuição praticamente se inverte: 12\% para bem e 4\% para bom. Esses resultados indicam que (i) no português, bom é o item privilegiado para atuar como MD no domínio funcional de chamada da atenção do interlocutor para a informação; e (ii) bem provavelmente apresente um espectro funcional mais alargado. A seguir, são examinados os usos de bem e bom como MDs.

\subsection{Bem e bom como MDs}

Considerando-se as características do gênero entrevista sociolinguística, bem como as funções das partículas bem e bom identificadas em outros trabalhos, foram estabelecidos alguns critérios para orientar a análise. Para a fala do informante, foram observados os tipos de contexto encabeçados pelos marcadores em questão: (i) em abertura de turno - o informante responde de imediato a

\footnotetext{
${ }^{12}$ Embora tais dados tenham sido considerados na categoria advérbio, mostram etapas do desenvolvimento do MD veja (bem), sendo registrados aqui a título de ilustração de um continuum categorial.
} 


\section{REVISTA DA ABRALIN}

pergunta do entrevistador, faz algum tipo de rodeio antes de responder ou se contrapõe ao interlocutor; (ii) intraturno - o informante rompe em alguma medida o fluxo discursivo; dá continuidade ao fluxo discursivo; retoma algo interrompido para dar sequência; introduz algum tipo de esclarecimento à informação precedente; introduz discurso direto; fecha o turno/tópico. Foram encontrados os tipos de contexto descritos a seguir.

- Resposta imediata convergente: o MD introduz uma resposta direta, colaborativa, pertinente ao teor da pergunta, conforme o esperado pelo entrevistador.

- Preâmbulo: o MD introduz um fundo/contextualização/repetição da pergunta que retarda, em alguma medida, o atendimento ao tópico proposto pelo entrevistador.

- Redirecionamento com ressalva: o MD introduz um reparo/contraposição na própria fala, redirecionando o conteúdo da resposta.

- Redirecionamento do (sub)tópico: o MD sinaliza uma espécie de ruptura, desviando, em alguma medida, o fluxo da informação.

- Sequenciação: o MD introduz um novo fato/comentário dando continuidade à resposta em curso, podendo retomar parcialmente a informação precedente para então prosseguir.

- Fechamento de turno/tópico: o MD encabeça uma conclusão em alguma instância.

- Retomada: o MD sinaliza retomada do fluxo informativo interrompido por digressões de diferentes extensões (não deixa de envolver também um certo redirecionamento).

- Justificativa/avaliação: o MD introduz uma justificativa/avaliação, explicando ou avaliando algo mencionado pelo próprio informante.

- Especificação de informação genérica: o MD introduz uma especificação de um tópico genérico desenvolvido pelo próprio informante.

- Introdução de discurso direto: o MD introduz um discurso direto. 


\section{REVISTA DA ABRALIN}

Esses tipos de contexto são ilustrados no Quadro 1, com uma ocorrência para cada item, quando possível. ${ }^{13}$

(1) E [...] Aqui o Bom Pastor, que é uma igreja que tem aqui que é da mesma paróquia que a minha ali perto, né? [...] não são sei se você frequenta muito lá...

F Bem, eu vou aos domingos algumas reuniões, mas não é sempre. (CTB Inf. 01) - Resposta imediata

(2) E E me dizes, tu disseste que faz bolo, assim, né? Como é que a gente faz bolo, Ana, me explica.

F Bom, tem que ter ovo, farinha açúcar, óleo ou manteiga, margarina, né? Uma gordura, alguns vai maisena, depende do bolo. (POA Inf. 08) - Resposta imediata

(3) E E em relação aos seus planos de futuro? [...] Quais os outros planos de futuro?

F Bem, nós temos um terreno em Viamão, estamos construindo uma casa, então o nosso plano é terminar essa casa, e talvez morar em Viamão, né? um lugar um pouco mais afastado, é menos barulho, mais tranquilo pra se morar [...]. (POA Inf. 04) - Preâmbulo

(4) E E depois mais tarde, quando o senhor foi ficando mais moço assim quais eram os divertimentos?

F Bom, divertimento aqui em Curitiba, quando eu era, tempo de rapaz, era mais [pra] no meu caso era mais o futebol, que eu gostava muito de futebol. [...] (CTB Inf. 17) - Preâmbulo

(5) E A mulher não perde-

F Não. Bem, isso aí é Forças Armadas. Mas que eu estou falando é do papai. E isso o Getúlio Vargas tirou. [...] (FLP Inf. 22) - Redirecionamento com ressalva

(6) F [...] Então ali tinha [um <esgo>] um rio, onde nós morávamos, aqui desse lado, subindo do lado esquerdo, onde enchia muito, fazia muito era uma casa de madeirinha, tudo simples, mas era muito bonito. A gente tinha criação, a gente tinha cavalos, carroça, meu pai tinha tudo isso! Quando enchia, todos os bichos tinham que ir pra dentro de casa, porque vinha água até aqui assim, né? faltava um dedo pra entrar dentro de casa.

$[\ldots]$

E E a senhora era criança, achava muito engraçado mesmo, né?

F Era bem engraçado. Era uma farra! Bom, daí meu pai disse assim- Aí nós juntávamos osso pra vender, tinha fábrica de osso. É, tudo isso, né? Minha vida foi sacrificada, também, né? Então nós íamos pelas ruas juntando osso. (CTB Inf. 14) - Redirecionamento com ruptura

(7) [...] Nisso aí começou o movimento do laboratório, chegar o pessoal, aí contei pra Maria. Disse: "Meu Deus da minha alma", disse: "Que coisa", e tal. Bem, voltei lá para o hospital e durante um, dois, três, no quarto dia, tá? a menina já tinha voltado, a barriga, ao normal, já estava evacuando normalmente, e foi indo, foi indo, até que ela saiu do hospital. Bem, nisso aí, talvez que tenha levado uns quinze dias, mais ou menos, ela já estava quase com um mês de idade, aí foi aquela coisa. (FLP Inf. 23) - Sequenciação

(8) F [...] Chegou cá e disse: "Senhores não viram meu vaca Chérie"? E ficou Bacacheri.

E Por causa da vaca dele.

F Da vaca que sumiu, que fugiu. Bom, de certo saiu namorar, né? porque ali era tudo fazenda de certo saiu namorar, e ele saía de atrás. Bom, lá é é sobre lá. (CTB Inf. 24) - Fechamento

(9) F [...] E eu, aí, fui trabalhar no SESI. [...] Agora, durante esse tempo, sem ser com caminhão, eu já viajei muito também, né? É Porto Alegre, Curitiba, São Paulo, Minas, e essa zona toda eu andei muito, assim, andava de carro, saía. Bem, mas [eu]- mas eu estava falando, inclusive, do SESI, né? Até aí fui, durante vinte e dois anos. (FLP Inf. 23) - Retomada/redirecionamento

\footnotetext{
${ }^{13}$ Os códigos dos dados significam: $\mathrm{E}$ = entrevistador; $\mathrm{F}$ = falante $/$ informante $\mathrm{I}=$ interveniente; $\mathrm{POA}=$ Porto Alegre; $\mathrm{CTB}=\mathrm{Curitiba}$; FLP = Florianópolis. Os códigos são seguidos pelo número do informante.
} 


\section{REVISTA DA ABRALIN}

(10) F [...] eu já fui fazer o serviço, e estava aquela turma no Centro, né? agitando, fazendo aquela coisa, aquela onda, houve aquela- uma depredação enorme em lojas [...] Mas havia uma situação política muito tensa no país, aquela história do Lacerda, do Major Vaz, que foi assassinado, né? então o povo se revoltou muito, porque o povo era muito getulista, realmente o Brasil era getulista, tanto prova a vitória esmagadora que ele teve quando ele foi eleito presidente do Brasil, não quando ele foi ditador, quando ele foi eleito realmente pelo povo, foi consagradora a vitória dele, a volta dele, né? pra presidência. Bom, e então eu fui pro Centro, estava com aquela pistola na cintura, pesava uma barbaridade, arma desse tamanho, né? [...] (POA Inf. 21) - Retomada/redirecionamento

(11) E $[\mathrm{Nem}]$ nem jogava assim?

F Eu jogar aqui, nunca joguei assim. Jogar assim eu nunca- jogar assim já às vezes eu jogava, mas jogava pouco, né? Tinha- tinha as pessoas que perdiam bastante, né? Perdiam quantias assim vultuosas, perdiam, né? Mas eu assim, jogava pouco, né? Bem, e aquele tempo também eu era garotão ainda, tinha quanto? Vinte e dois anos, vinte e um anos, né? Não era muito afeito assim ao jogo. (CTB Inf. 21) - Justificativa/avaliação

(12) E Eu sempre tive a impressão que agora era mais difícil criar os filhos, por causa do custo de vida

F Ah bom! só não, pelo custo de vida não. Bom! eu falo porque eu trabalhei por minha conta toda vida, e agora quem trabalha por conta própria leva muita vantagem, porque tudo que tu pegares tu vendes, não tem nada que tu não vendas, tudo é vendável, tudo é fácil de vender. (POA Inf. 18) - Justificativa/avaliação

(13) E E você falou que você é espírita. E é uma coisa que eu tenho curiosidade, eu acho que você pode me esclarecer alguma coisa no que diz respeito à reencarnação. Você pode me falar alguma coisa sobre isso?

F Posso. Posso falar bastante coisa. Bom, eh os católicos diziam que Lázaro ressuscitou, né? Na verdade, ele morreu e levantou no mesmo corpo, né? Eu já não acredito. Eu já acredito num mundo paralelo a este, um mundo espírita. (CTB Inf. 09) - Especificação

(14) F Aqui no bairro todo mundo conhece eles. [...] Pode perguntar em qualquer casa aí que todo mundo elogia ele. Ele era muito alegre, muito divertido assim, muito brincalhão. Todo mundo gostava dele. E eu digo pro meu irmão: "Bom, esse orgulho a gente tem, né?" Que que me adiantava meu pai me deixar uma fortuna e eu sair na rua, dizerem assim: "Olha lá, o pai daquela ali era um vigarista, um sem vergonha." né? (POA Inf. 24) - Discurso direto

\section{QUADRO 1 - Dados ilustrativos dos MDs beme bomna fala dos informantes}

Após a análise inicial e quantificação dos dados, esses contextos foram reorganizados com alguns agrupamentos em razão de comportamentos afins: os dois tipos de redirecionamento foram reunidos, os casos de fechamento se agregaram à sequenciação e os dados de especificação foram agrupados com justificativa/avaliação. Chegou-se, então, aos tipos de contexto expostos na Tabela 2. Esta tabela e as seguintes apresentam os dados das três capitais reunidos, pois o interesse aqui é focar nos contextos discursivos. 


\section{REVISTA DA ABRALIN}

\begin{tabular}{|c|c|c|c|c|c|c|}
\hline MDs & \multicolumn{2}{|c|}{ Bem } & \multicolumn{2}{|c|}{ Bom } & \multicolumn{2}{|c|}{ Total } \\
\hline Contextos & & $\%$ & $\mathrm{~N}$ & $\%$ & $\mathrm{~N}$ & $\%$ \\
\hline \multicolumn{7}{|c|}{ Abertura de turno } \\
\hline Preâmbulo & 02 & 07 & 90 & 36 & 92 & 33 \\
\hline Resposta imediata & 07 & 24 & 71 & 28 & 78 & 28 \\
\hline Total parcial & 09 & 31 & 161 & 65 & 170 & 62 \\
\hline \multicolumn{7}{|c|}{ Intraturno } \\
\hline Redirecionamento $^{14}$ & 03 & 10 & 35 & 14 & 38 & 14 \\
\hline Sequenciação $^{15}$ & 07 & 24 & 17 & 09 & 24 & 09 \\
\hline Justificativa/avaliação $^{16}$ & 02 & 07 & 16 & 06 & 18 & 06 \\
\hline Retomada & 08 & 28 & 10 & 04 & 18 & 06 \\
\hline Discurso direto & \multicolumn{2}{|c|}{-} & 08 & 03 & 08 & 03 \\
\hline Total parcial & 20 & 69 & 86 & 35 & 106 & 38 \\
\hline Total geral & 29 & 100 & 247 & 100 & 276 & 100 \\
\hline
\end{tabular}

TABELA 2 - Distribuição funcional dos MDs beme bomna fala dos informantes de acordo com o tipo de contexto que encabeçam

Fonte: elaboração própria

Primeiramente, cabe esclarecer que no universo de 72 informantes considerados: (i) 12 utilizaram bem como MD, 04 dos quais usaram apenas esse item; (ii) 50 fizeram uso de bom, 42 dos quais usaram apenas esse item. Nota-se, pois, que a ampla maioria dos falantes da amostra que usa esses marcadores prefere somente bom, enquanto 08 falantes fazem uso alternado de bem e bom e 04 utilizam apenas bem. Temos aqui um indicativo que, somado ao total de dados de bom (247 ocorrências) - quase nove vezes mais do que de bem (29 ocorrências) -, evidencia a larga preferência pelo uso desse marcador na fala dos informantes da Região Sul. ${ }^{17}$

Não obstante o desequilíbrio na quantidade de dados de bem e bom, os números da Tabela 2 indicam que todos os tipos de contexto introduzidos pelos marcadores (à exceção de discurso direto) são compartilhados pelos dois itens. O resultado mais relevante é o que diz respeito à posição dos MDs e funções associadas: embora a maioria do total dos itens se encontre em abertura de turno (correspondendo a 62\% do total de MDs), com predomínio de preâmbulo - e essa proporção seja relativamente mantida quando bom é tomado isoladamente -, essa taxa se inverte em relação a bem, com predomínio de resposta imediata sobre preâmbulo. Aliás, é interessante verificar que o percentual total de respostas imediatas (28\%) não fica tão distante do percentual total de preâmbulos (33\%), resultado de certa forma inesperado, uma vez que, de acordo com a literatura sobre o tema, esses

\footnotetext{
${ }^{14}$ Redirecionamento inclui 08 dados de bom em ruptura/desvio do tópico. Os demais são de redirecionamento com reparo.

${ }^{15}$ Sequenciação inclui 02 dados de bom e 02 dados de bem em fechamento de turno/tópico.

${ }^{16}$ Justificativa/avaliação inclui 06 dados de bom em contexto de especificação.

${ }^{17}$ Uma busca adicional por MDs em 12 entrevistas realizadas em Florianópolis com jovens (14 a 24 anos) mostrou apenas uma ocorrência de bem e 20 ocorrências de bom como MD, deixando ainda mais evidente que bom é o item preferencial para codificar o domínio funcional em questão.
} 


\section{REVISTA DA ABRALIN}

MDs teriam basicamente a função de adiar em alguma medida a resposta. Observando-se ainda os dois itens em posição de abertura de turno, há um resultado percentual aproximado em contexto de resposta imediata $($ bem $=24 \%$ e bom $=28 \%)$, o que, aliado aos resultados associados a preâmbulo $($ bem $=07 \%$ e bom $=36 \%)$, também não deixa de causar um certo estranhamento, pois a expectativa inicial era de que bem apareceria em contextos que demandassem mais esforço de elaboração.

Além disso, considerando os contextos reunidos, nota-se que enquanto bom predomina em abertura de turno, bem prepondera em posição intraturno, notadamente em retomada e sequenciação. O percentual de 38\% do total dos MDs funcionando no escopo da fala do próprio informante (somatório dos contextos intraturno) é bastante significativo à medida que aponta para estratégias de organização textual/discursiva do falante, que vai sinalizando tanto para o encadeamento sequencial das informações, como para retomadas, rupturas, esclarecimentos ou citações. Mais significativo ainda (apesar do número reduzido de dados) é o percentual de $69 \%$ de bem nesses contextos. Dentre as funções associadas aos tipos de contexto, preâmbulo, redirecionamento e justificativa/avaliação parecem ser as que demandam maior custo de processamento e maior posicionamento dos falantes, o que se esperava que propiciasse o uso de bem; mas não é o que ocorre na amostra, pois esse marcador se concentra mais em retomadas e sequenciação, sinalizando organização tópica.

Em um ângulo de visão distinto de Risso $(1999 ; 2006)$ - que identifica esses itens como "prefaciadores textual-interativos" que atuam em contextos de abertura seja de turno, seja de segmentos intraturno -, prefere-se considerar como abertura apenas as situações prototípicas de abertura de turno (e eventualmente a introdução de discurso direto), que têm caráter mais fortemente interativo, e analisar os usos intraturno como recursos de caráter mais textual. Nesse caso, caberia a bem o papel mais textual enquanto bom se concentraria em abertura de turno, com caráter mais interacional. Essa caracterização geral converge com a análise de Martins (2003), não obstante as diferenças que especificam os tipos de contexto. Note-se, porém, que não se trata de contrapor e discretizar interativo vs. textual, e sim conferir um peso maior a um ou outro componente em razão dos traços caracterizadores dos diferentes tipos de contexto.

As ocorrências dos MDs em contextos de redirecionamento com reparo ou com desvio de tópico - terceiro tipo de contexto mais frequente na amostra (total de 14\%) - apresentam resultado percentual aproximado para bem (10\%) e bom (14\%), sendo a grande maioria de ressalvas com atenuação ou uma certa contraposição a uma informação precedente, com traços de concessividade. Um dado interessante é que, tomados em conjunto o redirecionamento com ressalva e a introdução de preâmbulo sinalizando adiamento de resposta - contextos que expressam uma (re)elaboração do falante em relação ao tópico em pauta -, o percentual de bem nessas funções é de apenas 17\%, ao passo que o percentual de bom sobre para aproximadamente $50 \%$.

Contextos de sequenciação, justificativa/avaliação e retomada são responsáveis por 21\% do total de dados analisados (59\% das ocorrências de bem e 19\% das ocorrências de bom), revelando o caráter mais textual de bem em relação a bom. Por fim, a abertura de discurso direto aparece na amostra apenas com o marcador bom. 


\section{REVISTA DA ABRALIN}

Em síntese: Como MDs, bem e bom (i) compartilham um amplo domínio funcional de chamada da atenção do interlocutor para a informação a ser proferida numa situação dialógica, num movimento simultaneamente interpessoal e textual; (ii) retêm, em alguns contextos e em algum grau, traços de avaliação positiva do significado de origem, inferíveis da validação do falante acerca do que foi dito, e também apresentam novos traços com gradientes de distanciamento/ discordância, percebidos nos movimentos de ruptura, ressalva, explicação; (iii) ocorrem tanto em abertura de turno como em posição intraturno; (iv) coexistem com os itens lexicais de origem [cf. princípios da estratificação, da persistência e da divergência de Hopper (1991)]. Esse comportamento geral comum permite que os itens sejam tratados conjuntamente.

Paralelamente, contudo, os MDs apresentam especificidades funcionais na fala dos informantes: além do largo predomínio de bom sobre bem, este ocorre mais em posição intraturno do que aquele, notadamente sinalizando retomada e sequenciação; bom ocorre preferencialmente em abertura de turno; nessa posição, bem aparece mais em resposta imediata, enquanto bom ocorre majoritariamente em contexto de preâmbulo. Tais comportamentos convergem com o princípio de especialização: tanto por generalização (HOPPER, 1991) - mais claramente -, quando uma forma assume a codificação do amplo domínio funcional; como por especificação (TAVARES, 1999) - menos claramente -, quando há contextos preferenciais para uma e outra forma no mesmo domínio.

Os resultados obtidos apontam que ambos os marcadores coexistem num mesmo domínio funcional de chamada de atenção para a informação numa situação dialógica, mas apresentam especificidades de uso. Tais especificidades, na amostra analisada, convergem apenas parcialmente com as funções descritas para os itens correlatos em outras línguas, notadamente no que diz respeito ao traço de discordância/contraposição em relação ao interlocutor, que se mostra bastante tênue nos dados aqui analisados, com certos traços presentes apenas em alguns contextos de preâmbulo. Os redirecionamentos, contextos que mais se aproximam de algum tipo de contraposição, ocorrem intraturno e têm escopo sobre a fala do próprio informante. Provavelmente, em amostra de conversas cotidianas espontâneas o posicionamento do falante emerja mais fortemente, sem receio de se contrapor ao interlocutor.

Como já dito, foram levantadas também as ocorrências dos MDs bem e bom na fala do entrevistador, dado o caráter dialógico das entrevistas sociolinguísticas. Como adiantado na seção precedente, o pesquisador segue em geral um roteiro previamente estabelecido de tópicos a serem abordados, buscando fazer com que o informante discorra o máximo possível sem interferências. Essa característica da amostra naturalmente se reflete nos usos desses marcadores pelo entrevistador, que vão aparecer sempre em abertura de turno, seja dando início à entrevista, seja em troca de turno.

Os seguintes tipos de contexto contendo os MDs foram encontrados na fala do entrevistador.

- $\quad$ Abertura da entrevista: o MD introduz a entrevista.

- Introdução de novo (sub)tópico: o MD sinaliza mudança no rumo da conversa. 


\section{REVISTA DA ABRALIN}

- $\quad$ Retomada de tópico: o MD sinaliza retomada de um assunto já abordado, dando sequência ou introduzindo um novo (sub)tópico.

- Comentário/pergunta e sequenciação: o MD introduz um comentário ou uma pergunta em relação à fala do informante, mantendo a sequenciação tópica. ${ }^{18}$

(15) E Bem, então vamos começar a nossa entrevista. Tu vais nos contar tudo o que tu sabes do bairro desde a tua infância até agora.

F Sim. (POA Inf. 13) - Abertura da entrevista

(16) E Bom, estamos aqui na casa da Dona Maria, né? Dona Maria da Silva, e vamos começar agora a gravação da fita maior, né? A gente já fez a fita menor e agora vamos continuar, né? a conversa com a Dona Maria.

F Pois é, né? Vamos lá, ver o que resolvemos conversar hoje. (СTB Inf. 20) - Abertura de entrevista

(17) E E a família dele na época. Bom, ele era casado já na época ou não?

F Não, era solteiro. Ele era solteiro e casou depois.

E Bem, sobre a sua vida profissional. Eu gostaria que o Senhor falasse um pouco sobre como foi a sua vida. O serviço do Senhor, o que que o Senhor fazia?

F Bom, como funcionário público eu ingressei em cinquenta e oito, na função de tesoureiro, que eles diziam o pagador, não é? (CTB Inf. 15) - Introdução de novo (sub)tópico

(18) E Uma pessoa querida, né?

F É, muito querida.

E Marca, né?

F Marca.

E Bom, mudando um pouquinho de assunto, né? Aqui, na tua casa, quem faz o trabalho doméstico? É mais tu ou são divididas as tarefas? (FLP Inf. 17) - Introdução de novo (sub)tópico

(19) F Bom, você vê, há muita exploração nessas seitas. Acabei de ver, agora na televisão aí, um que comprou a TV Record, os milhões que arrecadou e está sendo processado por curas, que não foram feitas- realizado cura nenhuma, só engano do povo, não é? [...]

E Sei. Bem, passando agora [pra] novamente pra parte dos estudos. É, o senhor me falou que quando o senhor começou a fazer o científico e depois teve que parar, né? porque o seu pai era guarda-livro e queria que o senhor continuasse com a profissão.

F Exato. (CTB Inf. 15) - Retomada de tópico

(20) E Então tu trabalhas sessenta horas semanais e ganhas?

F Doze pela efetividade, né? E pela substituição, que são vinte horas, dá cinco mil e pouco.

E Só pra esclarecer. Bom, e tu falaste que tu gostas muito de carnaval, né? Tu participas das escolas de samba?

F Carnaval. Sim.

E Ah, então conta pra mim como é que é. (FLP Inf. 17) - Retomada de tópico

(21) F Pois então. É- Aí eu disse assim pra mulher: "Eu comprei coxa de peru." Ela: "Não, quanto está hoje? Não sei como-." "Eu comprei porque está muito na promoção". Ela disse assim: "Só compra coisa na promoção." Está certo! Se eu fosse comprar coisa mais- Que que é? Eu não sou capitalista.

E Está barato mesmo. Quarenta e cinco.

F Está quarenta e cinco. Um quilo de galinha, setenta.

\footnotetext{
${ }^{18}$ Houve apenas um caso de comentário e fechamento da entrevista, que foi computado junto a comentário/pergunta.
} 


\section{REVISTA DA ABRALIN}

E É. E bem, e galinha, a gente tira a carcaça, sobra pouca coisa.

F É- é perfeitamente. É é quarenta e cinco e noventa. (FLP Inf. 06) - Comentário/pergunta e sequenciação

(22) F Eu acho que vai melhorar. Acredito que vai melhorar. É só o Collor não voltar atrás nas suas decisões, né? que a tendência é melhorar. No começo foi difícil, hoje já melhorou um pouco. Vamos ver pra frente. A tendência é melhorar.

E Você então concorda com as medidas? Bom, pelo menos algumas?

F Em termos. Em termos, eu concordo. Não concordo com todas, né? Mas em termos eu concordo. (CTB Inf. 11) - Comentário/pergunta e sequenciação

QUADRO 2 - Dados ilustrativos dos MDs beme bom na fala dos entrevistadores

Há uma incidência alta de MDs na fala do entrevistador (110 ocorrências), como mostram os resultados na Tabela 3.

\begin{tabular}{l|cc|cc|cc}
\hline \multicolumn{1}{c|}{ MDs } & \multicolumn{2}{|c|}{ Bem } & \multicolumn{2}{c|}{ Bom } & \multicolumn{2}{c}{ Total } \\
\hline \multicolumn{1}{c|}{ Contextos } & $\mathrm{N}$ & $\mathrm{N} / \%$ & $\mathrm{~N}$ & $/ \%$ \\
\hline Abertura da entrevista & 01 & 10 & 08 & 08 & 09 & 08 \\
\hline Introdução de novo (sub)tópico & 04 & 40 & 48 & 48 & 52 & 47 \\
\hline Retomada de tópico & 02 & 20 & 22 & 22 & 24 & 22 \\
\hline Comentário/pergunta e sequenciação & 03 & 30 & 22 & 22 & 25 & 23 \\
\hline Total & 10 & 100 & $100 / 100$ & 110 & 100 \\
\hline
\end{tabular}

TABELA 3 - Distribuição funcional dos MDs beme bom na fala dos entrevistadores de acordo com o tipo de contexto que encabeçam

Fonte: elaboração própria

No geral, os MDs são relativamente pouco usados na abertura da entrevista (aparecem em 09 das 72 entrevistas) e o item bom ocorre dez vezes mais do que bem, sendo a forma largamente preferida também pelo entrevistador. Os MDs se concentram mais na introdução de novo (sub)tópico, redirecionando a entrevista - o que era esperado, pois cabe ao pesquisador controlar as trocas de turno -, e aparecem também tanto em retomadas de tópico como em comentários, em que o entrevistador atua colaborativamente buscando assegurar a coerência e coesão discursiva tanto em nível macro como em nível micro.

Observa-se, pois, que mesmo no âmbito de um gênero particular (a entrevista sociolinguística), os mesmos marcadores apresentam-se com comportamento diferenciado na fala do informante e na fala do entrevistador. Os itens bem e bom compartilham entre os interlocutores a tendência de frequência de uso (bom dispara como marcador preferencial) e o fato de ambos aparecerem em vários tipos de contexto. Na fala do entrevistador, porém, diferentemente da fala do informante, a distribuição dos itens por tipo de contexto é equilibrada. Essas distinções funcionais podem ser atribuídas aos diferentes papéis desempenhados pelos interlocutores no gênero discursivo em questão. É interessante observar também que em (17) bem e bom aparecem em abertura de turno na fala do entrevistador e do informante, respectivamente. 


\section{REVISTA DA ABRALIN}

\subsection{Beme bom: outros usos}

Além de aparecerem como advérbio/adjetivo e MD, os itens bem e bom apresentam também outros usos. As tabelas a seguir mostram os usos encontrados na fala dos informantes.

\begin{tabular}{l|cc}
\hline Outros usos & $\mathrm{N} /$ & $\%$ \\
\hline Expressão cristalizada & 98 & 60 \\
\hline Substantivo & 23 & 14 \\
\hline Se bem que & 28 & 17 \\
\hline Bem que & 07 & 04 \\
\hline Ainda bem que & 05 & 03 \\
\hline Ainda bem & 03 & 02 \\
\hline Total & 164 & 100 \\
\hline
\end{tabular}

TABELA 4 - Outros usos de bem na fala dos informantes Fonte: elaboração própria

Foram consideradas como expressões cristalizadas: tudo bem (77 ocorrências), bem dizer (12 ocorrências), por bem (03 ocorrências), bem de vida (02 ocorrências), o bem estar (02 ocorrências), bem feito! (01 ocorrência) e gente de bem (01 ocorrência).

Seguem alguns dados ilustrativos desses outros usos.

(23) E Ah, tu já tens um filho de quinze e uma de dezessete anos, é?

F É. Hoje, apesar do meu filho estar trabalhando, tudo bem, mas ele ainda depende um pouco de mim, né? Mas hoje não. Hoje depende mais dele, que ele ganha o salário dele. (FLP, Inf. 18)

A expressão tudo bem aparece - tanto na fala do próprio entrevistado como em discurso direto reportado - em contextos de concordância, aceitação ou avaliação positiva de uma situação precedente enunciada por um interlocutor ou pelo próprio falante, sendo seguida ou de algum tipo de ressalva ou contraposição (cf. 23), ou de continuidade do tópico, com explicações ou simples sequenciação, e eventualmente em fechamento de tópico. Normalmente significa "está/tudo certo", "ok". Embora faça um movimento fórico duplo (à exceção do fechamento), tem um caráter mais fortemente anafórico, diferentemente do marcador bem que, na amostra analisada, apresenta também um acentuado escopo catafórico. Parece haver um deslizamento funcional gradiente: tudo bem = movimento anafórico de concordância; bem/bom = movimento catafórico de abertura de turno, ou de sinalização de ruptura ou de introdução de novas informações no fluxo discursivo. É interessante notar a diferença numérica entre os dados de tudo bem (77 ocorrências) e do MD bem (29 ocorrências). A relação entre a emergência e desenvolvimento dos usos de tudo bem, bem e bom é uma questão que fica em aberto.

Há ainda uma ocorrência de cumprimento em que as fórmulas tudo bom? e tudo bem? se alternam numa conversa entre um interveniente e o entrevistado, mostrando mais um contexto de coexistência de usos de bem e bom. 


\section{REVISTA DA ABRALIN}

(24) I Tudo bom? Eu só vim trazer a chave.

F Oi, Lenir, tudo bem? Está ok, tá? (FLP Inf. 22)

A expressão bem dizer ocorre com valor de modalização, significando "praticamente".

(25) F [...] Tinha que ficar até às nove acordado, não podia deitar e depois do pernoite podia dormir e de manhã cinco e meia os primeiros a acordar éramos nós. Nossa! minha revolta veio toda daí e virei, bem dizer, um mau elemento dentro do quartel. (CTB Inf. 09)

Como substantivo, bem aparece em contextos como (26).

(26) F [...] Uma coisa que poderia ser usada a serviço do bem, a serviço do ser humano, né? Está servindo para destruição, destruir o ser humano. (POA Inf. 02)

As expressões se bem que, bem que, ainda bem que e ainda bem somam 43 ocorrências, dentre as quais a primeira é a mais frequente na amostra. Os dados a seguir exemplificam esses usos.

(27) E Ô, Ana, e o que você está achando do Governo do Collor?

$[\ldots]$

E Será que vai melhorar?

F Ah! Eu acho que não, né? Do jeito que ele- que está, como diz que nosso salário só vai ser aumentado em janeiro, eu acho isso um absurdo! Como eu hoje: o meu salário veio dezesseis mil, aí tem o desconto da Associação, ficam quinze mil. Eu, no supermercado, gasto dez, doze, quer dizer, é a metade pra mim, metade pro meu marido. Vamos que seja cinco pra cada, eu vou ficar com nove- Fico com dez. Tenho coisa pra pagar. Se bem que eu almoço no RU, né? mas eles, em casa. E eu, eu como bem, agora eles... (FLP Inf. 09)

(28) E E hoje quais são os problemas que a senhora vê aqui no bairro além desses de infraestrutura assim, não ter bancos, né? Escolas têm aqui?

F Tem escolas. Tem. Tem aqui perto da minha casa, na mesma quadra da minha casa tem a Rafael Pinto Bandeira, tem o Emílio Massot, tem o Fernando Ferrari um pouquinho mais adiante, tem o colégio Padre Reus, é na Tristeza, tem o segundo grau, mas bem que poderia ter mais, né? (POA Inf. 02)

(29) F [...] Mesmo no emprego, não dou moleza pra patrão. Nem pra patrão, nem pra gerente. Encheu o saco, eu mando à merda. Eu acho que ninguém tem obrigação de escutar desaforo, entende? Eu acho que não é só porque é funcionário que é escravo. E eu gosto de trabalhar. Ainda bem que nessa empresa eu trabalho à vontade. Não tem ninguém que te enche o saco. (CTB Inf. 11) 


\section{REVISTA DA ABRALIN}

(30) E O senhor está casado há muito tempo?

F Vai pra lá de vinte anos, e sou muito bem com a minha mulher, graças a Deus. A minha família, todo mundo bem, com saúde. Ainda bem, né? (FLP Inf. 14)

O valor concessivo de se bem que é evidente em (27). A entrevistada emitia sua opinião sobre o baixo salário na época do governo Collor e gastos de supermercado, quando interrompe a sequência de fatos desfavoráveis e redireciona a linha expositiva ao introduzir um aspecto positivo - ela almoçava no RU, portanto se alimentava bem -, contrapondo a seguir o fato de que seus familiares almoçavam em casa, donde se infere que não se alimentavam bem. O significado concessivo também está presente em bem que (28), reforçado por "mas" precedente. A informante enumerava as escolas existentes no bairro e faz a ressalva de que poderia ter mais.

Em (29) e (30), ainda bem que e ainda bem introduzem um comentário de avaliação positiva, no sentido de "que bom", "menos mal". Por guardarem traços de avaliação positiva presentes no significado original do advérbio bem, provavelmente essas expressões tenham antecedido o uso concessivo de (se) bem que em sua trajetória de gramaticalização.

Na amostra analisada não foi encontrada nenhuma ocorrência de bem funcionando como partícula modal, no sentido de "recursos linguístico-discursivos utilizados com a função de modalizar informações não explícitas durante a interação" (AQUINO; ARANTES, 2020 p. 166), tal como em: "Você bem (que) recebeu a minha mensagem, né?" (p. 182) - uso em que a partícula "faz referência a uma contraexpectativa forte por parte do ouvinte" (p. 183).

\begin{tabular}{l|cc}
\hline \multicolumn{1}{c|}{ Outros usos } & $\mathrm{N}$ & $/ \%$ \\
\hline Expressão cristalizada & 14 & 45 \\
\hline Interjeição & 11 & 36 \\
\hline Substantivo & 06 & 19 \\
\hline Total & 31 & 100 \\
\hline
\end{tabular}

TABELA 5 - Distribuição de outros usos de bom Fonte: elaboração própria

Entre as expressões cristalizadas encontram-se: (nada/tudo/algo) de bom (11 ocorrências), tudo bom (02 ocorrências) e bota bom (01 ocorrência). Exemplos:

(31) E Tu chegaste a conhecer a cidade? Um pouco?

F Pouca coisa. Muito pouca coisa. Conheço a Avenida Paulista só e A Santa Ifigênia, que é a rua das eletrônicas, né? E conheci a boca: Major Sertório, aquela bocada lá. Que mais, os shoppings, né? Morumbi. Mas o povinho lá é brabo! Diz que a noite paulista é boa, mas eu não vi nada de bom lá. O que eu vi é muito paulista trancado em pizzaria comendo, só. (POA Inf. 23) 


\section{REVISTA DA ABRALIN}

(32) F Eu comecei a fumar com catorze anos. (Dirigindo-se ao interveniente) Oi, Roberto, tudo bom? Que que tu queres? (FLP Inf. 04)

(33) E Gosta de morar em Porto Alegre?

F Gosto. Bah! bota bom nisso! (POA Inf. 11)

Foram considerados usos interjetivos as expressões ah bom! como em (34), como expressão de reação subjetiva sinalizando concordância com a fala do entrevistador.

(34) E Eu sempre tive a impressão que agora era mais difícil criar os filhos, por causa do custo de vida.

F Ah bom! só não, pelo custo de vida não. Bom! eu falo porque eu trabalhei por minha conta toda vida, e agora quem trabalha por conta própria leva muita vantagem, porque tudo que tu pegares tu vendes, não tem nada que tu não vendas, tudo é vendável, tudo é fácil de vender. (POA Inf. 18)

As expressões interjetivas retêm mais claramente traços positivos do adjetivo bom, o que sugere que, historicamente, usos com esse valor tenham antecedido o uso de bom como MD conforme os dados analisados. É provável que expressões interjetivas desse tipo tenham derivado de está bom, como em (35), dado computado como adjetivo neste trabalho e que merece atenção em uma análise da trajetória de mudança a partir de bom adjetival.

(35) E É, nós estávamos falando da televisão.

F: Está bom. É parte de futebol, né? (FLP Inf. 05)

Por fim, o uso de bom como substantivo é ilustrado em (36).

(36) E Aí fica como tapeçaria.

F: Fica que nem tapeçaria. Eu tenho duas encomendas dessa bonequinha aqui, não sei quando eu vou poder fazer. Mas eu já estou super a fim de fazer. O bom é que uma já fiz, esse aqui, com esses eu já fiz essa bonequinha aqui, esse aqui, esse e agora eu estou fazendo esse aqui, ó. (POA Inf. 20)

Em síntese: o item bem mostra-se mais recorrente em outros usos (164 ocorrências) do que bom (31 ocorrências). Outros usos de bem são distribuídos em seis categorias, com destaque para expressões cristalizadas (notadamente tudo bem) e para a construção concessiva gramaticalizada (se) bem que. Outros usos de bom são classificados em três categorias, com destaque também para expressões cristalizadas (especialmente nada/tudo de bom). Esse resultado evidencia que bem tem um comportamento mais polissêmico do que bom e que vem desenvolvendo mais instâncias diversificadas de gramaticalização. 


\section{REVISTA DA ABRALIN}

\section{Considerações finais}

Sob uma perspectiva funcionalista que incorpora aspectos discursivo-pragmáticos no escopo da gramática e sob a ótica da gramaticalização como expansão, notadamente expansão semânticopragmática que atravessa os planos textual e interpessoal, este artigo apresentou uma descrição sincrônica da multifuncionalidade dos itens bem e bom, com ênfase em seu uso como MDs, em dados gerados a partir de entrevistas sociolinguísticas, com foco no contexto dialógico.

O controle da frequência mostrou que (i) os usos inovadores - MDs e "outros usos" - ocorrem concomitantemente aos usos de base - bem adverbial e bom adjetival - (cf. princípio da divergência de Hopper (1991); (ii) o item bem é o mais recorrente na amostra (61\% de bem e $39 \%$ de bom); (ii) os usos prototípicos das categorias de base são os mais produtivos (85\% de bem como advérbio e $66 \%$ de bom como adjetivo); (iii) no âmbito do domínio funcional da chamada de atenção para a informação, onde os itens atuam como MDs (cf. princípio de estratificação de Hopper (1991)), bem é menos usado do que bom (02\% de bem e 30\% de bom); (iv) bem supera seu concorrente em "outros usos" (12\% de bem e 04\% de bom), mostrando um leque mais amplo de expansões polissêmicas. No domínio funcional em questão, bom tem praticamente uso generalizado (247 ocorrências /89\%) ao passo que bem apresenta uso marginal (29 ocorrências/11\%) (cf. princípio da especialização por generalização de Hopper (1991)).

No que diz respeito aos contextos de uso dos MDs, as partículas aparecem em abertura de turno (62\%) e em posição intraturno (38\%). No primeiro tipo de contexto, especialmente em respostas diretas, ambos os itens retêm, por transferência metonímica, o traço de avaliação positiva de origem (cf. princípio da persistência de Hopper (1991)), inferível da postura de concordância do informante aceitando falar sobre o que lhe foi proposto. Tomados isoladamente, porém, os itens se manifestam em distribuição complementar: bem predomina em posição intraturno (69\%) com menor frequência em abertura de turno (31\%), ao passo que bom prevalece em abertura de turno (65\%) com presença menor em posição intraturno (35\%). Além disso, em termos frequenciais, bem se destaca em contextos de retomada (28\%), de sequenciação (24\%) e de resposta imediata (24\%) - os dois primeiros intraturno e o último em abertura de turno; bom, por sua vez, se concentra encabeçando preâmbulo (36\%) e resposta imediata (28\%) - ambos em abertura de turno. Esse comportamento diferenciado sugere traços ainda incipientes de especialização de uso (cf. princípio da especialização por especificação, nos termos de Tavares (1999)).

Em consonância com outros estudos realizados sobre os usos discursivos dessas partículas, verificou-se que o uso dos MDs sinaliza um duplo movimento: de estruturação discursiva - encabeçando abertura/fechamento/sequenciação -, e de negociação - indiciando algum tipo de posicionamento do falante em relação ao discurso precedente (do entrevistador ou dele próprio). Em outras palavras, os itens tanto acomodam o enunciado na situação dialógica da troca de turnos, como organizam o fluxo informacional atuando como estratégias retóricas de chamada de atenção e contribuindo para a coesão e coerência discursiva. 


\section{REVISTA DA ABRALIN}

Diferentemente dos resultados de outros estudos, porém, que atestam fortemente o uso dos marcadores correlatos, notadamente bien/well, como alerta de desacordo ou contraposição em relação ao enunciado precedente do interlocutor, na amostra aqui analisada esse tipo de confronto com a fala do entrevistador não aparece ou aparece de forma tênue em respostas com preâmbulo. A postura do informante no que diz respeito à expressão de seus pontos de vista, por exemplo, fica mais evidente com o MD em posição intraturno, em situações de redirecionamento e/ou de retomada e de elaboração de justificativas ou explicações, que demandam certo esforço de processamento; e tais usos incidem sobre a fala do próprio informante e não sobre a fala do entrevistador.

Essas diferenças provavelmente tenham relação com a natureza da amostra analisada. As entrevistas sociolinguísticas, no caso, envolvem uma negociação colaborativa - o entrevistador deseja obter dados vernaculares, por isso procura deixar o informante à vontade; o entrevistado, por sua vez, busca ser cooperativo, já que se dispôs à conversa. Considera-se, pois, que o funcionamento dos itens é dependente do tipo de situação comunicativa. Na análise levada a cabo neste artigo, essa dependência do contexto fica visível quando se comparam os usos dos MDs na fala do informante e na fala do entrevistador. Os gêneros discursivos e suas particularidades, a partir dos quais os dados são gerados, precisam ser considerados nas análises, especialmente em estudos comparativos e na formulação de generalizações.

Como desdobramento deste trabalho e de modo a melhor delinear o espectro funcional dos itens, a próxima etapa seria uma análise diacrônica para captar as trajetórias de mudança a partir das formas e significados fonte, contemplando a emergência de usos e o desenvolvimento de diferentes instâncias de gramaticalização ao longo do tempo, em diferentes gêneros textuais/discursivos, buscando encontrar também usos de bem como partícula modal.

\section{REFERÊNCIAS}

AQUINO, M.C.; ARANTES, P.C.C. Partículas modais em alemão e seus equivalentes funcionais em português brasileiro: proposta de análise e classificação para o uso. Pandaemonium Germanicum, v. 23, n. 40, p. 166-190, 2020. DOI: 10.11606/1982-88372340166. Acesso em: 15 julho 2020.

BRINTON, L. J.; TRAUGOTT. E. C. Lexicalization and language change. Cambridge University Press, 2005.

BYBEE, J. Mechanisms of change in grammaticization: the role of frequency. In: JOSEPH, B. D.; JANDA, R. D. (eds.)

The handbook of Historical Linguistics. Oxford: Blackwell Publishing, 2003, p. 602-623.

DE FINA, A. An analysis of Spanish bien as a marker of classroom management in teacher-student interaction. Journal of Pragmatics, v. 28, p. 337-354, 1997.

DEFOUR, T. A diachronic study of the pragmatic markers well and now: Fundamental research into semantic development and grammaticalisation by means of a corpus study. 2007, PhD dissertation. Universiteit Gent, Faculteit Letteren en Wijsbegeerte, Vakgroep Engels, 2007, 339p. 


\section{REVISTA DA ABRALIN}

DEGAND, L.; EVERS-VERMEUL, J. Grammaticalization or pragmaticalization of discourse markers? More than a terminological issue. Journal of Historical Pragmatics, v. 16, n. 1, p. 59-85, 2015. DOI:10.1075/jhp.16.1.03deg. Acesso em: 15 julho 2020.

DIEWALD, G. Pragmaticalization (defined) as grammaticalization of discourse functions. Linguistics, v. 49, n. 2, p. 365-390, 2011a. DOI 10.1515/LING.2011.011. Acesso em: 15 julho 2020.

DIEWALD, G. Grammaticalization and pragmaticalization. In: NARROG, H.; HEINE, B. (eds.). The Oxford handbook of grammaticalization. Oxford: Oxford University Press, 2011b, p. 450-461.

DU BOIS, J. W. The stance triangle. In: ENGLEBRETSON, R. (ed.). Stancetaking in discourse: subjectivity, evaluation, interaction. Amsterdam: John Benjamins, 2007, p. 139-182.

GIVÓN, T. Syntax. v. 1. Amsterdam: John Benjamins, 2001.

GIVÓN, T. On understanding grammar. New York, Academic Press, 1979.

GIVÓN, T. On understanding grammar. Revised edition. Amsterdam: John Benjamins, 2018.

HALLIDAY, M. A. K. An introduction to functional grammar. 2. ed. London: Edward Arnold, 1994 [1985].

HEINE, B. On discourse markers: Grammaticalization, pragmaticalization, or something else? Linguistics, v. 51, n. 6, p. 1205-1247, 2013. DOI 10.1515/ling-2013-0048. Acesso em: 15 julho 2020.

HERITAGE, J. Well-prefaced turns in English conversation: A conversation analytic perspective. Journal of Pragmatics, v. 88, p. 88-104, 2015. DOI 10.1016/ j.pragma.2015.08.008. Acesso em: 18 julho 2020.

HIMMELMANN, N. P. Lexicalization and grammaticization: Opposite or orthogonal? In: BISANG, W.; HIMMELMANN, N. P.; WIEMER, B. (eds.). What makes grammaticalization: A look from its fringes and its components. Berlin/New York: De Gruyter Mouton, 2004, p. 21-42.

HOPPER, P. On some principles in the grammaticalization. In: TRAUGOTT, E. C.; HEINE, B. (eds.). Approaches to grammaticalization, v. 1. Amsterdam: John Benjamins, 1991, p. 7-35.

HOPPER, P.; TRAUGOTT, E. Grammaticalization. 2. ed. Cambridge: Cambridge University Press, 2003.

MARTINS, L. 'Bom'e 'bem' e suas multifunções na fala da Região Sul do Brasil. (2003). 106f. Dissertação (Mestrado em Linguística) - Programa de Pós-Graduação em Linguística, Universidade Federal de Santa Catarina, Florianópolis, 2003.

RISSO, M. S. Aspectos textuais-interativos dos marcadores discursivos de abertura bom, bem, olha, ah, no português culto falado. In: NEVES, M. H. de M. (org.). Gramática do português falado, v. VII. Novos estudos. São Paulo: Humanitas/USP; Campinas: Editora da Unicamp, 1999, p. 259-296.

RISSO, M. S. Marcadores discursivos basicamente sequenciadores. In: JUBRAN, C. C. A. S; KOCH, I. G. V. (orgs.). Gramática do português culto falado no Brasil, v. 1. Campinas/SP: Editora da Unicamp, 2006, p. 427-496.

SAKITA, T. Discourse markers as stance markers: Well in stance alignment in conversational interaction. Pragmatics \& Cognition, v. 21, n. 1, p. 81-116, 2013. DOI 10.1075/pc.21.1.04sak. Acesso em: 18 julho 2020.

SERRANO, M. J. Bueno como marcador discursivo de inicio de turno y contraposicion: estudio sociolinguístico. International Journal of the Sociology of Language, v. 140, p. 115-133, 1999. 


\section{REVISTA DA ABRALIN}

TAVARES, M. A. Um estudo variacionista de AÍ, DAÍ, ENTÃO e E como conectores sequenciadores retroativopropulsores na fala de Florianópolis. (1999). 175f. Dissertação (Mestrado em Linguística) - Programa de PósGraduação em Linguística, Universidade Federal de Santa Catarina, Florianópolis, 1999.

TRAUGOTT, E. C. The role of the development of discourse markers in a theory of grammaticalization. Manchester: Stanford University, p.1-29, 1995.

TRAUGOTT, E. C. From etymology to historical pragmatics. In: MINKOVA, D.; TOCKWELL, R. (eds.) Studying the history of the English language: Millennial perspectives. Berlin/New York: De Gruyter Mouton, 2002, p. 19-49.

TRAUGOTT, E. Constructions in Grammaticalization. In: JOSEPH, B. D.; JANDA, R. D. (eds.) The Handbook of Historical Linguistics. Oxford: Blackwell Publishing, 2003, p. 624-647.

TRAUGOTT, E. C. All that he endeavoured to prove was...“: On the emergence of grammatical constructions in dialogic contexts. In: COOPER, R.; KEMPSON, R. (eds.). Language in Flux: Dialogue Coordination, Language Variation, Change and Evolution. Londres: Kings College Publications, p. 143-177, 2008.

TRAUGOTT, E. C. Grammaticalization. In: LURAGHI, S.; BUBENIK, V. (eds.) Continuum companion to historical linguistics. London/New York: Continuum International Publishing Group, 2010a, p. 269-283.

TRAUGOTT, E. C. Revisiting subjectification and intersubjectification. In: DAVIDSE, K.; VANDELANOTTE, L.; CUYCKENS, H. (eds.) Subjectification, intersubjectification and grammaticalization. Berlin/New York: De Gruyter Mouton, 2010b, p. 29-70.

TRAUGOTT, E. C. Dialogic contexts as motivations for syntactic change. In: CLOUTIER, R. A.; HAMILTONBREHM, A. M.; KRETZSCHMAR, W. A. (eds.) Variation and change in English grammar and lexicon: contemporary approaches. Berlin/New York: De Gruyter Mouton, 2010c, p. 11-27.

TRAUGOTT, E. C.; DASHER, R. B. Regularity in semantic change. Cambridge: Cambridge University Press, 2002.

TRAUGOTT, E.; HEINE, B. Instroduction. In: TRAUGOTT, E.; HEINE, B. (eds.) Approaches to grammaticalization, v. 1. Amsterdam: John Benjamins, 1991, p. 01-14.

TRAVIS, C. Bueno: a Spanish interactive discourse marker. In: BERGEN, B. K.; PLAUCH'E, M. C.; BAILY, A. C. (eds.), PROCEEDINGS OF THE 24TH ANNUAL MEETING OF THE BERKELEY, LINGUISTICS SOCIETY, February, 14-16. Berkeley: University of California, Berkeley, p. 268-279, 1998.

VALLE, C. R. M.; GÖRSKI, E. M. Por um tratamento multidimensional da variação estilística na entrevista sociolinguística. In: GÖRSKI, E. M.; COELHO, I. L.; NUNES DE SOUZA, C. M. (Org.). Variação estilística: reflexões teórico-metodológicas e propostas de análise. Florianópolis: Insular, 2014, p. 93-121.

WALTEREIT, R.; DETGES, U. Different functions, different histories. Modal particles and discourse markers from a diachronic point of view. Catalan Journal of Linguistics, v. 6, p. 61-80, 2007.

WIERZBICKA, A. Semantics: primes and universals. Oxford: Oxford University Press, 1996. 